\title{
Medicus curat: sungazing versus spectacles?
}

\author{
Francesca Albini ${ }^{1} \cdot$ Michele Augusto Riva $\mathbb{C}^{2}$
}

Received: 15 January 2020 / Revised: 20 January 2020 / Accepted: 21 January 2020 / Published online: 29 January 2020

(c) The Royal College of Ophthalmologists 2020

"Medicus curat, Natura sanat, the doctor treats, nature heals" [1]. The quote of this ancient aphorism opens Chapter 1 of The Art of Seeing of the British writer Aldous Huxley (1894-1963), a book published in 1942, which supports the Bates method for improving eyesight without spectacles. A severe attack of keratitis in his youth left Huxley with very poor vision and the need to rely on thick glasses in order to read. When his condition deteriorated further, he became intrigued with the Bates method, and found considerable improvement following its techniques. The Art of Seeing strives to make a correlation between the methods of visual education and psychology, the connection between the eye and the mind. It also brings to the attention that, historically, the eye has been treated differently from other organs. While physicians create the conditions for the body to heal itself, in the case, say, of putting a broken bone in a cast, dressing a wound, administering medicines to boost the immune system, the solution to a defective sight seems to be limited to the spectacle, a mere crutch that does not cure, improve, stops or even slows down the visual defect.

In 1920 William Horatio Bates (1860-1931), a successful American ophthalmologist, who studied at Cornell and Columbia universities, published the book Perfect Sight Without Glasses, which claims that all sight problems are due to eye strain, and lays out a method of improving eyesight through various techniques-palming, visualization, movement, and, most controversial of all, sunning, i.e., sungazing [2].

The worship of sun gods and the belief in the healing powers of the sun are to be found in all recorded history. To

Francesca Albini

franalbini@gmail.com

1 Royal Society for the Encouragement of Arts, Manufactures and Commerce, London, UK

2 School of Medicine and Surgery, University of Milano-Bicocca, Monza, Italy mention just one example, in Greek mythology, the giant Orion violates queen Merope, and gets blinded by her father. His eyesight is then restored by the rays of the morning sun. The Greek god of the sun, Helios, was indeed believed to heal the blind, since he was son of the Titaness Theia (Sight). Ancients indeed sustained that the human eye emitted an invisible beam, which allowed one to see whatever it touched. The Greek philosopher Plato stated, "it [the vision] is the most sunlike of all the instruments of sense" (Republic, 508c). In the Middle Ages, the poet Dante Alighieri (1265-1321) again related sun and vision in his Divine Comedy (Paradise, XXX, 25), confirming his interest in eyesight and its alterations [3].

William Bates' life is shrouded in mystery. He was at the height of his career in New York City, when he suddenly disappeared in 1902. His wife managed to track him down to London a couple of months later. He looked emaciated, and was suffering from some form of amnesia, he did not recognize her and had no recollection of his past. Two days later he walked out of the Savoy hotel where Mrs Bates had taken him for a period of rest, to finally reappear in Grand Forks, North Dakota in 1910, when his friend, Dr J.E. Kelly chanced upon him. Kelly persuaded his colleague to go back to New York where they opened a practice together. Bates never recovered his memory and spent the following years honing a revolutionary and highly controversial method to cure defective eyesight. The results were published at his own expenses in the aforementioned book, which was illustrated by a number of rather bizarre photos of people in the act of sungazing.

What happened to Bates during his long disappearance and how linked it is to the development of his theory is hard to tell, but the practice of sungazing, together with a rebellion against spectacles must have been in the air in the first decades of the twentieth century. In 1911, G.K. Chesterton (1874-1936) published a Father Brown story called The Eye of Apollo, where a self-proclaimed New Priest of Apollo teaches his followers to stare at the sun. One of his disciples is a young woman who is a fierce supporter of modern technology, such as lifts, telephones, 
and typewriters, yet she flings her sister's spectacles to the floor and stamps on them. She calls them "sickly medical notions..., badges of poltroonery" [4]. Apollo, a sun god, was believed to be a healer, especially of the eyes.

In the first decades of the twentieth century the relationship between illness and the mind was being explored by Sigmund Freud (1856-1939), Franz Alexander (1891-1964), and other psychiatrists. The physician Georg Groddeck (1866-1934), pioneer of psychosomatic medicine, was researching the possibility of curing physical disorders with the use of psychology. In 1913 he published a book entitled Nasamecu, which is an acronym of the Latin motto 'Natura Sanat, Medicus Curat', also quoted by Huxley in his work [5]. In later articles, Groddeck agreed with Bates that spectacles should be abolished or used in moderation, and that exercise, visualization, and exploration of the psychological sides of human sight should be employed instead.

Ironically, it was in the early 1900s that sunglasses were first mass-produced, courtesy of Sam Foster, and Hollywood stars turned them into an essential fashion item for everyone, encouraging, according to Huxley, the fear of light.

But where is science at today, 100 years later? We are still wearing glasses or contact lenses, and the advice not to stare at the sun with the naked eye still stands strong. Yet, some of the points raised by Bates are being revisited in a new light (pardon the pun). Age related macular degeneration and chorioretinal conditions are now treated with photodynamic therapy, where a medicine is used which is activated by near infrared light [6]. Other forms of light treatments are the subject of photobiology, and some improvements in the sight of patients with macular degeneration has been noticed when exposed to low-level light therapy or photobiomodulation-where patients look into a beam of light shined into their eyes by a special device [7].

On the front of spectacles, the massively increased myopia rate around the world and in East Asia in particular, where it affects as much as $90 \%$ of young adults, calls for prevention and treatment of eyesight defects, and for alternatives to visual aids such as glasses. Many studies are carried out that seem to indicate that increased time outdoors is effective in preventing the onset of myopia [6], and in children and adults when they lead and active life in general, keep their weight healthy, but also undergo controlled vision therapy [8].

As to the worship of the sun and sungazing, the practice is still alive and well (with the caveat of "don't try this at home"), mainly thanks to the charismatic researcher into solar healing, Hira Ratan Manek, who has been living on sun energy, water, and the occasional glass of buttermilk since 1995 .

\section{Compliance with ethical standards}

Conflict of interest The authors declare that they have no conflict of interest.

Publisher's note Springer Nature remains neutral with regard to jurisdictional claims in published maps and institutional affiliations.

\section{References}

1. Huxley A. The art of seeing. New York: Harper and Brothers; 1942.

2. Bates WH. Perfect sight without glasses. New York: Central Fixation Publishing Co.; 1920.

3. Riva MA, Arpa C, Gioco M. Dante and asthenopia: a modern visual problem described during the Middle Ages. Eye. 2014;28:498.

4. Chesterton GK. The Innocence of Father Brown. London, New York, Toronto and Melbourne: Cassell \& Co Ltd; 1911.

5. Groddeck G. Nasamecu. Der gesunde und kranke Mensch gemeinverständlich dargestellt. Leipzig: Hirzel; 1913.

6. Newman DK. Photodynamic therapy: current role in the treatment of chorioretinal conditions. Eye. 2016;30:202-10.

7. Ao J, Wood JP, Chidlow G, Gillies MC, Casson RJ. Retinal pigment epithelium in the pathogenesis of age-related macular degeneration and photobiomodulation as a potential therapy? Clin Exp Ophthalmol. 2018;46:670-86.

8. Xiong S, Sankaridurg P, Naduvilath T, Zang J, Zou H, Zhu J, et al. Time spent in outdoor activities in relation to myopia prevention and control: a meta-analysis and systematic review. Acta Ophthalmol. 2017;95:551-66. 